\title{
John Ingleson
}

Workers, Unions and Politics. Indonesia in the 1920s and 1930s. Leiden and Boston:

Brill, 2014, xvii + 352 pp. [Southeast Asian Library, Volume 2]. ISBN 9789004264465.

Price: EUR 125.00 (hardback).

In recent years, Indonesia has seen a remarkable rise of labour activism. With massive May Day rallies in 2012 and 2013 and with public interventions of unions in the presidential elections of 2014 it appears that labour activism has regained the strength it had lost during the New Order decades of Suharto. In a new book, issued by Brill publishers, emeritus professor John Ingleson shows that unionism in Indonesia has a long and turbulent past.

Over the years, Ingleson has published extensively on Indonesia's early twentieth century labour movement and anticolonial politics. Workers, Unions and Politics is the long-awaited sequel to the book In search of Justice, which was published in 1986. In search of Justice described the 'first phase' of Indonesia's modern trade union movement until the defeat of the 1925 Surabaya and Semarang strikes and the destruction of the PKI a year later. Workers, Unions and Politics continues the narrative where In search of Justice stopped and focuses on the period from the second half of the 1920s until the end of the colonial era.

Workers, Unions and Politics gives a good impression of the labour relations in the urban centres of Java and the general political and socio-economic climate in the colony in the 1930s, using union periodicals and publications, newspaper articles, and government reports as main sources. In two opening chapters, Ingleson describes how employers and the colonial state exercised effective control over the kampung and the urban workforce, and, conversely, how labour unions tried to challenge employers, the colonial state and worker's subservience and disillusion. The subsequent four chapters give a chronologic overview of the variable and at times chaotic landscape of unions, federations, and political parties, mostly in Java. Constrained by limited source material, Ingleson focuses mainly on the formal and (semi)public side of economy. Workers in the railway, postal, pawn shop, and educational sectors were generally best organised. By contrast, unions in sugar factories, small workshops, and harbours, which were covered more extensively in In search ofJustice, are less dealt with in this new book. This is also true for the masses of Indonesian workers in the informal economy, household economies, and in agriculture.

Nonetheless, Ingleson is successful in describing how unions in the 1930s challenged the constraints enforced upon them by the colonial government and employers. They gradually shifted their activities from overt and confrontational politics towards the establishment of less vocal social institutions, such

(C) KLAAS STUTJE, 2014 | DOI: 10.1163/22134379-17004006

This is an open access article distributed under the terms of the Creative Commons 
as insurance companies, mutual benefit societies, legal protection services, and education. Although these social structures did not acquire political prominence, they provided a natural school for thousands of urban workers in hundreds of union branches to gain experience in organising, managing, and political struggle. Moreover, Ingleson shows that the main site of contestation in the 1930s shifted from the eloquent and political union elite vis-à-vis the colonial government, towards the union chapters and branches, where workers contested all-powerful foremen, arbitrary treatment by employers, and constant pressure on jobs and wages. Particularly interesting is the observation that some higher anticolonial political objectives, such as the Indianisation of the economy, had undesirable effects on the shop floor, with employers replacing European and Eurasian personnel with Indonesian workers in order to press wage costs. Within the unions, debates were held on the relations between unions and political parties, between the union's head office and branches, and on race versus class based politics. Below the surface of 'tranquillity and order', Ingleson suggests that the 1930 s were crucial formative years for Indonesian rank-and-file members and union leaders, and had 'a significant impact on the programs and actions of labour unions after independence' (p. 333).

With this last comment, Ingleson risks overplaying his hand somewhat. Although his point seems reasonable, and is mainly directed to authors who see the 1930 as a decade of general workers apathy and government control, he does not work out how exactly the experiences of the 193os resonated in the 1940s. Also, Ingleson leaves us with the question of how to characterise labour activism in the 1930s. Although he offers us abundant material on union activities and debates in this period, this does not prove that these years were equally significant compared to the decades before and after. Reading the empirical chapters, one cannot escape the impression that with suffocating state repression, massive redundancies by companies, a full stop of strike actions, harsh censorship on newspapers, and a general fear among workers to organise, labour unions in Indonesia in the 1930s were on the retreat and struggling to prove their relevance to workers.

Nonetheless, Unions, Workers and Politics is a valuable contribution to our knowledge of the 'missing years' of Indonesia's pre-independence labour movement, and sharpens our understanding of the complex relationship between Indonesia's political elite and the urban workforce, fighting for social rights and wage justice. It's a complicated relationship that is continually redefined in Indonesia today.

\section{Klaas Stutje}

University of Amsterdam

k.stutje@uva.nl 